G.I. Messiahs 
This page intentionally left blank 


\section{G.I. Messiahs}

Soldiering, War, and

American Civil Religion

\section{Jonathan H. Ebel}

Yale UNIVERSITY PRESS

NEW HAVEN AND LONDON 
Published with assistance from the Mary Cady Tew Memorial Fund.

Copyright $\left(C^{2} 2015\right.$ by Yale University.

All rights reserved.

This book may not be reproduced, in whole or in part, including illustrations, in any form (beyond that copying permitted by Sections 107 and 108 of the U.S. Copyright Law and except by reviewers for the public press), without written permission from the publishers.

Yale University Press books may be purchased in quantity for educational, business, or promotional use. For information, please e-mail sales.press@yale.edu (U.S. office) or sales@yaleup.co.uk (U.K. office).

Set in Ehrhardt type.

Printed in the United States of America.

ISBN: 978-0-300-I7670-4 (hardback; permanent paper)

Library of Congress Control Number: 2015936435

A catalogue record for this book is available from the British Library.

This paper meets the requirements of ANSI/NISO Z39.48-I992 (Permanence of Paper).

Iо 98765432 I 
To Mom and Dad

Thank you 
This page intentionally left blank 